\title{
An Innovative Study of E-Payment Systems Adoption in Higher Education: Theoretical Constructs and Empirical Analysis
}

\author{
https://doi.org/10.3991/ijim.v13i06.9875 \\ Said A. Salloum \\ University of Fujairah, Al Fujairah, UAE \\ Mostafa Al-Emran $(\varpi)$ \\ Ton Duc Thang University, Ho Chi Minh City, Vietnam \\ al.emranetdtu.edu.vn \\ Rifat Khalaf, Mohammed Habes \\ University of Fujairah, Al Fujairah, UAE \\ Khaled Shaalan \\ The British University in Dubai, Dubai, UAE
}

\begin{abstract}
Examining the adoption of e-payment systems is not a new research topic. Nevertheless, studying the factors affecting the adoption of epayment systems in higher educational institutions is a new research trend. Thus, this study is considered one of the few that attempts to investigate the factors affecting the e-payment systems adoption in six different universities in the United Arab of Emirates (UAE). A total number of 289 students took part in the study. This study proposed a new research model in which the students' intention to use the e-payment systems are affected by five different factors including perceived benefit, performance expectancy, perceived risk, perceived security/privacy, and trust. The partial least squares-structural equation modeling (PLS-SEM) approach was used to validate the research model. The empirical results suggested that perceived benefit and performance expectancy have a significant positive relationship with the students' intention to use e-payment systems, whereas perceived security/privacy and perceived risk exhibited a significant negative relationship. However, the results triggered out that trust has an insignificant relationship with the students' intention to use e-payment systems. The results acquired from this research provide a fresh and an up-to-date information on the e-payment systems adoption in the higher educational institutions.
\end{abstract}

Keywords-E-payment, adoption, higher education, structural equation modeling, UAE. 


\section{$1 \quad$ Introduction}

Individuals are now more inclined towards online transactions due to the progress and trust made in Internet technology, especially in the field of Internet banking [1]. Electronic payment (e-payment) is the core of Internet Banking, which refers to the online platform that forms the basis for online shopping, online auctions, and Internet stock trading [2]. Individuals using the Internet are benefitted through Internet banking as it is very convenient compared to the traditional payment methods that use cash or check for payment transactions while involving queues and physical visits.

It is argued that there are two types of perceived benefits that could be achieved while using online banking, and these are classified as direct and indirect advantages [3]. The tangible benefits achieved instantly by the customers are the direct advantages gained while using online banking. These benefits can be seen in the form of financial benefits, transaction speed, and increased information transparency. On the other side, the intangible benefits gained by customers through online banking are the indirect advantages [3]. The example in this regard is that online banking transactions can be carried out in anytime anywhere settings by providing better investment options and services to customers such as stock quotations and latest news [2].

It is anticipated that there is an increasing number of Internet banking users in general, and the e-payment systems in particular. However, the level of these systems acceptance by their end-users is still in short supply [4], [5]. Several restrictions were noticed in the traditional e-payment systems which could constrain the users from adopting them [6]. According to the previous research, the shortage of security, privacy, performance expectancy, trust, perceived benefits, and perceived risk are a few factors among these restrictions [7]. Prior to the usage of e-payment systems, the endusers must ensure that these factors are enabled effectively to make them convenient during the transaction processes. Conversely, it can be further stated that consumers may lose confidence in online activities in the case that these fundamentals are not met in the payment systems, which may result in the loss of business opportunities.

Security is among the most significant issues that has engulfed the e-payment systems. Owing mainly to the fact that there is no personal contact is created among the stakeholders before the transfer of funds and information online. The credit card scam is the biggest worry in this regard [8]. Customers making e-payments are also threatened by another factor that is perceived risk [6]. Hackers are always looking for personal information and credit card particulars that form a major threat, which is another concern for customers. E-payment transactions should be trustworthy enough as this represents the core of online applications usage and adoption [7].

In the education sector, the higher educational institutions are working hard to encourage the use of e-payment systems; however, the rate of students adoption is still quite low [9], [10]. The benefits of e-payment services are depreciated due to the concerns observed in the face of privacy and security. A large number of research was conducted to examine the factors affecting the consumers adoption of e-payment systems [11]-[13]. According to the literature, it has been argued that the main constituents of the consumer market are the business executives, university students, and retail users of banking services [1], [14]-[17]. 
Among those users, the university students' adoption of e-payment systems is still in short supply, and requires further examination. The importance of those users' adoption refers to the fact that university students constitute a considerable major part in the market due to their educational status and extensive usage of Internet services. In addition, technology adoption has become a key research field by many information systems scholars, and this refers to the fact that the factors affecting these technologies are varied from one context to the other [18]-[20]. E-payment systems are one of such technologies that attracted the attention of many scholars. However, there is a limited number of research studies conducted to understand the factors affecting e-payment adoption in higher education. Based on the previous assumptions, the present study is an attempt to empirically examine the factors affecting the university students' adoption of e-payment systems in six different universities in the United Arab of Emirates (UAE).

\section{Research Model and Hypotheses Development}

The research model of this study is developed through the integration of five different factors, namely perceived benefit, perceived security/privacy, perceived risk, trust, and performance expectancy along with the intention to adopt e-payment systems. Figure 1 demonstrates the developed research model.

\subsection{Perceived benefit}

Perceived benefit (PB) refers to "the perception of the positive consequences that are caused by a specific action" [21]. The perceived benefit of e-payment system refers to the overall payment experience by saving time and vigor and providing more scenarios to financial benefits [22]. According to the literature, perceived benefit was shown to have a significant effect on internet banking [2], and corporate website adoption [23]. Thus, the following hypothesis is formulated:

H1: Perceived benefit has a positive impact on students' intention to adopt epayment system.

\subsection{Perceived security/privacy}

Perceived security (PS) refers to a "consumer's perception that the Internet vendor will fulfill security requirements such as authentication, integrity, encryption, and non-repudiation" [24]. Perceived privacy and perceived security are connected to each other where perceived privacy is a part of perceived security. The opinion regarding privacy risk and inadequate security in Internet banking was shown to have an impact on the customers' adoption [25], [26]. The biggest hindrance to online banking usage is the security issues; thus, the utilization of e-payment systems is affected [27]. As a result, it can be said that the users' decision to use e-payment systems is dependent on the security/privacy [23]. Therefore, the following hypothesis is formulated: 
H2: Perceived security/privacy has a negative impact on students' intention to adopt e-payment system.

\subsection{Perceived risk}

Perceived risk (PR) is defined as the direct effect in the online transaction of users' adoption intention [28]. According to the literature, perceived risk was revealed to have a significant effect on the adoption of e-payment systems [1], [6], [29]-[32]. As a result, this study formulates the following hypothesis:

H3: Perceived risk has a negative impact on students' intention to adopt e-payment system.

\subsection{Trust}

Trust refers to the extent to which the individuals' trust in e-payment systems can be accomplished through the accumulation of individuals' beliefs of integrity and ability to leverage their willingness to use e-payment systems in their financial transactions [11]. It is believed that the higher the trust in the e-payment systems, the lower the risk associated with such systems is perceived [23]. According to the extant literature, trust was found to have a significant impact on the consumers' adoption of epayment systems [11]-[13], [17], [33]-[35]. Therefore, this leads to the following hypothesis:

H4: Trust has a positive impact on students' intention to adopt e-payment system.

\subsection{Performance expectancy}

Performance expectancy (PE) refers to "the degree to which an individual believes that applying the technology will help him or her to attain gains in job performance" [36]. Individuals can only be inclined to use and accept a particular technology when they realize that using the technology will add more benefits to their daily lives [11], [36]. Performance expectancy was found to be a significant factor in determining the behavioral intention to use e-payment systems [1], [11], [33], [37]-[39]. Thus, this study formulates the following hypothesis:

H5: Performance expectancy has a positive impact on students' intention to adopt e-payment system. 


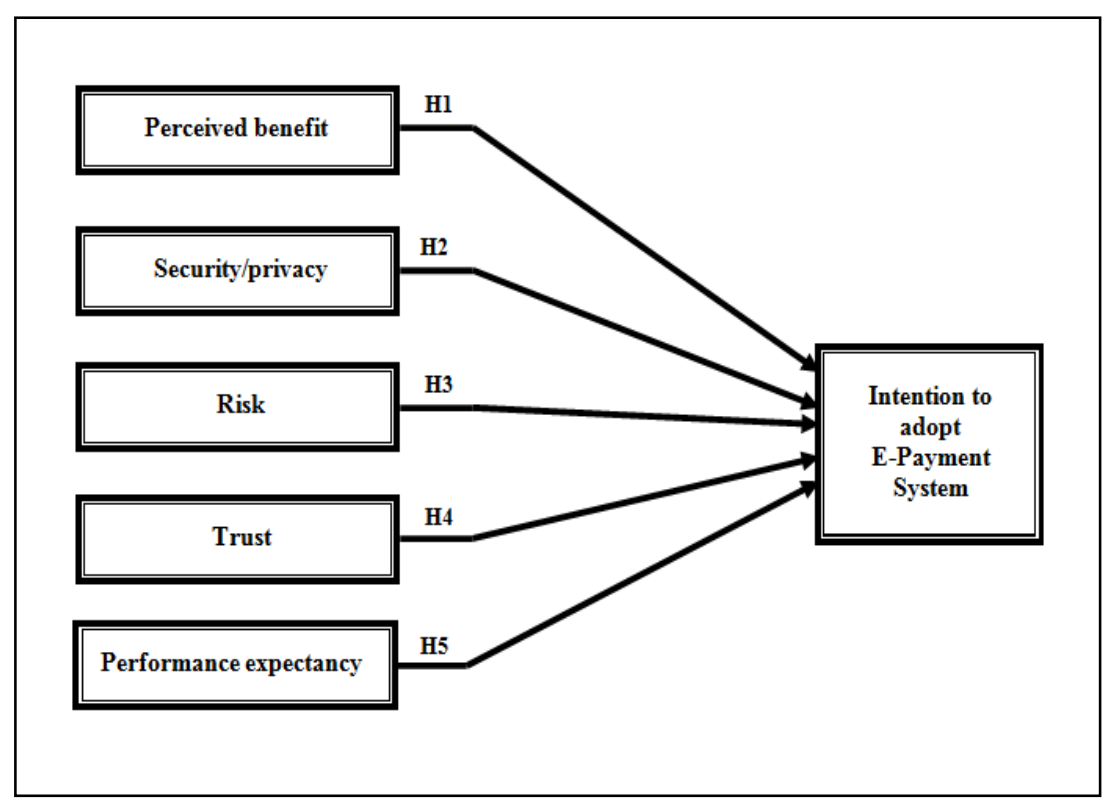

Fig. 1. Research model

\section{$3 \quad$ Research Methodology}

\subsection{Data collection}

The university students in six different universities in the United Arab of Emirates (UAE) are the target population of this study. These universities include Abu Dhabi School of Management (ADSM), Al Ain University of Science and Technology (AAU), The British University in Dubai (BUiD), University of Dubai (UOD), University of Fujairah (UOF), and University of Sharjah (UOS). The convenience sampling approach is employed during the process of data collection. This was the same procedure followed in recent studies concerning technology adoption and acceptance [40][42]. In order to determine the minimum required sample size, the $G^{*}$ Power tool was employed [43]. The $\mathrm{G}^{*}$ Power parameters include the values of 0.35 as the effect size, 0.01 as the error type $(\alpha), 0.8$ as the power, and 5 as the number of predictors. The minimum required sample size was found to be 193 . Accordingly, a total of 300 questionnaire surveys were distributed among the students in the targeted universities. 11 responses were dropped out due to the missing values observed in most of the items in the survey. Overall, there were 289 valid responses in hand which could be used for further analysis. 


\subsection{Instrument development}

Most of the researchers refer to the currently available measurements in the literature that perform well in previous studies [44], [45]. This is the same procedure followed in the present study. The constructs, number of items, and their corresponding sources are demonstrated in Table 1. The participants have to state their levels of agreement to the given constructs by reacting to the survey items. The answer to each item follows the five-point Likert scale in which " 1 = strongly disagree, 2 = disagree, $3=$ neutral, $4=$ agree, and $5=$ strongly agree".

Table 1. Constructs and their sources

\begin{tabular}{|l|c|l|}
\hline \multicolumn{1}{|c|}{ Constructs } & Number of items & \multicolumn{1}{c|}{ Source } \\
\hline Intention to adopt E-Payment System & 6 & {$[11],[33],[46],[38],[38]$} \\
\hline Perceived benefit & 4 & {$[2],[46],[23],[22]$} \\
\hline Performance expectancy & 4 & {$[11],[33],[39],[47],[38]$} \\
\hline Risk & 4 & {$[39],[32],[2],[34]$} \\
\hline Security/privacy & 4 & {$[2],[47],[35],[23],[48]$} \\
\hline Trust & 4 & {$[11],[12],[2],[35],[23]$} \\
\hline
\end{tabular}

\section{$4 \quad$ Findings and Discussion}

\subsection{Data analysis}

In order to analyze the collected data and examine the formulated research hypotheses, the Partial Least Squares-Structural Equation Modeling (PLS-SEM) approach was employed using Smart PLS 3.2.7 [49]. This study follows a two-step approach in validating the developed model; these two steps include the assessment of both the "measurement model" and "structural model". The measurement model (outer model) represents the relationship between the constructs and their indicators, whereas the structural model (inner model) refers to the relationship between the latent constructs [50].

\subsection{Sample profile}

Table 2 exhibits the respondents' characteristics, in which $47 \%$ of them were males, and $53 \%$ were females in which this ratio is usually observed in most of the studies in the domain. Most of the respondents were bachelor and master's degree students (39\%), aged between 18 and 29 years (56\%). The majority of the respondents were under the College of Business Administration (35\%) and the College of Engineering and Information Technology (30\%). Most of the respondents were located in the Emirate of Fujairah (32\%). 
Table 2. Respondents' characteristics

\begin{tabular}{|c|c|c|c|}
\hline Variables & Answers & Frequency & Percentage \\
\hline \multirow{2}{*}{ Gender } & Female & 153 & $53 \%$ \\
\hline & Male & 136 & $47 \%$ \\
\hline \multirow{4}{*}{ Age } & 18 to 29 & 163 & $56 \%$ \\
\hline & 30 to 39 & 74 & $26 \%$ \\
\hline & 40 to 49 & 34 & $12 \%$ \\
\hline & 50 to 59 & 18 & $5 \%$ \\
\hline \multirow{5}{*}{ College } & College of Business Administration & 102 & $35 \%$ \\
\hline & College of Humanities and Social Sciences & 33 & $12 \%$ \\
\hline & $\begin{array}{l}\text { College of Engineering and Information Technolo- } \\
\text { gy }\end{array}$ & 86 & $30 \%$ \\
\hline & College of General Education & 41 & $4 \%$ \\
\hline & $\begin{array}{l}\begin{array}{l}\text { College of Mass Communication and Public Rela- } \\
\text { tions }\end{array} \\
\end{array}$ & 27 & $9 \%$ \\
\hline \multirow{3}{*}{$\begin{array}{l}\text { Level of educa- } \\
\text { tion }\end{array}$} & Bachelor & 114 & $39 \%$ \\
\hline & Master & 113 & $39 \%$ \\
\hline & Doctorate & 62 & $22 \%$ \\
\hline \multirow{7}{*}{ Location } & Abu Dhabi & 39 & $14 \%$ \\
\hline & Dubai & 84 & $29 \%$ \\
\hline & Sharjah & 18 & $6 \%$ \\
\hline & Ajman & 20 & $7 \%$ \\
\hline & Umm al-Quwain & 18 & $6 \%$ \\
\hline & Ras al-Khaimah & 18 & $6 \%$ \\
\hline & Fujairah & 92 & $32 \%$ \\
\hline
\end{tabular}

\subsection{Measurement model assessment}

Hair and his colleagues suggested estimating the internal consistency reliability, convergent validity, and discriminant validity for assessing the measurement model [50]. The internal consistency reliability was measured using the composite reliability (CR) and Cronbach's alpha. The convergent validity was measured using the factor loading, and average variance extracted (AVE). The discriminant validity was assessed using the Fornell-Larcker criterion, cross-loadings, and the HeterotraitMonotrait ratio (HTMT).

As illustrated in Table 3, the Cronbach's alpha and CR values of all the variables were greater than the suggested value of 0.7 . Moreover, the values of factor loadings of all the items were greater than the recommended value of 0.7. Additionally, the AVE values of all the constructs in the model were greater than the threshold value of 0.5 . Therefore, the convergent validity and the internal consistency reliability were confirmed. 
Table 3. Convergent validity and internal consistency reliability

\begin{tabular}{|c|c|c|c|c|c|}
\hline Constructs & Items & Factor Loading & Cronbach's Alpha & CR & AVE \\
\hline \multirow{6}{*}{$\begin{array}{l}\text { Intention to adopt E- } \\
\text { Payment System }\end{array}$} & ADOPTION_1 & 0.783 & \multirow{6}{*}{0.863} & \multirow{6}{*}{0.897} & \multirow{6}{*}{0.594} \\
\hline & ADOPTION_2 & 0.789 & & & \\
\hline & ADOPTION_3 & 0.815 & & & \\
\hline & ADOPTION_4 & 0.819 & & & \\
\hline & ADOPTION_5 & 0.785 & & & \\
\hline & ADOPTION_6 & 0.791 & & & \\
\hline \multirow{4}{*}{ Perceived benefit } & BENEFIT_1 & 0.867 & \multirow{4}{*}{0.873} & \multirow{4}{*}{0.913} & \multirow{4}{*}{0.724} \\
\hline & BENEFIT_2 & 0.896 & & & \\
\hline & BENEFIT_3 & 0.820 & & & \\
\hline & BENEFIT_4 & 0.817 & & & \\
\hline \multirow{4}{*}{$\begin{array}{l}\text { Performance expectan- } \\
\text { cy }\end{array}$} & PER_EXP_1 & 0.788 & \multirow{4}{*}{0.753} & \multirow{4}{*}{0.833} & \multirow{4}{*}{0.559} \\
\hline & PER_EXP_2 & 0.784 & & & \\
\hline & PER_EXP_3 & 0.831 & & & \\
\hline & PER_EXP_4 & 0.841 & & & \\
\hline \multirow{4}{*}{ Risk } & RISK_1 & 0.877 & \multirow{4}{*}{0.777} & \multirow{4}{*}{0.857} & \multirow{4}{*}{0.601} \\
\hline & RISK_2 & 0.812 & & & \\
\hline & RISK_3 & 0.809 & & & \\
\hline & RISK_4 & 0.796 & & & \\
\hline \multirow{4}{*}{ Security/privacy } & SEC_PRIV_1 & 0.784 & \multirow{4}{*}{0.792} & \multirow{4}{*}{0.864} & \multirow{4}{*}{0.615} \\
\hline & SEC_PRIV_2 & 0.772 & & & \\
\hline & SEC_PRIV_3 & 0.848 & & & \\
\hline & SEC_PRIV_4 & 0.778 & & & \\
\hline \multirow{4}{*}{ Trust } & TRUST_1 & 0.787 & \multirow{4}{*}{0.814} & \multirow{4}{*}{0.878} & \multirow{4}{*}{0.642} \\
\hline & TRUST_2 & 0.825 & & & \\
\hline & TRUST_ 3 & 0.797 & & & \\
\hline & TRUST_4 & 0.796 & & & \\
\hline
\end{tabular}

Table 4 shows the Fornell-Larker criterion, in which the square roots of AVE should be greater than its correlation with other constructs [51]. It is exhibited from Table 4 that the Fornell-Larcker criterion is confirmed. Table 5 shows the crossloadings results, in which the loading of each indicator should be higher than the loadings of its corresponding constructs' indicators. As it can be seen from Table 5, the cross-loadings criterion is ascertained. Table 6 shows the HTMT ratio, in which the values of each construct should not exceed the threshold value of 0.85 [52]. Based on the readings in Table 6, the HTMT ratio is met. As a result, the discriminant validity is confirmed. The analyses results provide an evidence that there were no issues regarding the assessment of the measurement model in terms of its reliability and validity, and thus, the gathered data can be further used to evaluate the structural model. 
Table 4. Fornell-Larcker criterion

\begin{tabular}{|l|c|c|c|c|c|c|}
\hline & $\begin{array}{c}\text { Intention to } \\
\text { adopt E-Payment } \\
\text { System }\end{array}$ & $\begin{array}{c}\text { Perceived } \\
\text { benefit }\end{array}$ & $\begin{array}{c}\text { Performance } \\
\text { expectancy }\end{array}$ & Risk & Security/privacy & Trust \\
\hline $\begin{array}{l}\text { Intention to adopt E- } \\
\text { Payment System }\end{array}$ & 0.771 & & & & & \\
\hline Perceived benefit & 0.605 & 0.851 & & & & \\
\hline $\begin{array}{l}\text { Performance expec- } \\
\text { tancy }\end{array}$ & 0.565 & 0.468 & 0.748 & & & \\
\hline Risk & 0.619 & 0.618 & 0.493 & 0.775 & & \\
\hline Security/privacy & 0.491 & 0.660 & 0.387 & 0.588 & 0.784 & \\
\hline Trust & 0.623 & 0.521 & 0.576 & 0.668 & 0.523 & 0.801 \\
\hline
\end{tabular}

Table 5. Cross-loadings

\begin{tabular}{|c|c|c|c|c|c|c|}
\hline Items & $\begin{array}{l}\text { Intention to adopt } \\
\text { E-Payment System }\end{array}$ & $\begin{array}{c}\text { Perceived } \\
\text { benefit }\end{array}$ & $\begin{array}{l}\text { Performance } \\
\text { expectancy }\end{array}$ & Risk & Security/privacy & Trust \\
\hline ADOPTION_1 & 0.783 & 0.440 & 0.442 & 0.510 & 0.387 & 0.479 \\
\hline ADOPTION_2 & 0.789 & 0.530 & 0.421 & 0.523 & 0.422 & 0.453 \\
\hline ADOPTION_3 & 0.815 & 0.501 & 0.410 & 0.520 & 0.445 & 0.495 \\
\hline ADOPTION_4 & 0.819 & 0.485 & 0.470 & 0.507 & 0.376 & 0.581 \\
\hline ADOPTION_5 & 0.785 & 0.372 & 0.368 & 0.349 & 0.298 & 0.434 \\
\hline ADOPTION_6 & 0.791 & 0.454 & 0.498 & 0.430 & 0.330 & 0.431 \\
\hline BENEFIT_1 & 0.540 & 0.867 & 0.453 & 0.544 & 0.584 & 0.451 \\
\hline BENEFIT_2 & 0.588 & 0.896 & 0.411 & 0.549 & 0.553 & 0.455 \\
\hline BENEFIT_3 & 0.465 & 0.820 & 0.408 & 0.516 & 0.508 & 0.446 \\
\hline BENEFIT_4 & 0.446 & 0.817 & 0.309 & 0.492 & 0.613 & 0.422 \\
\hline PER_EXP_1 & 0.278 & 0.218 & 0.788 & 0.280 & 0.198 & 0.301 \\
\hline PER_EXP_2 & 0.263 & 0.207 & 0.784 & 0.271 & 0.186 & 0.279 \\
\hline PER_EXP_3 & 0.507 & 0.385 & 0.831 & 0.396 & 0.337 & 0.535 \\
\hline PER_EXP_4 & 0.536 & 0.488 & 0.841 & 0.472 & 0.369 & 0.516 \\
\hline RISK_1 & 0.439 & 0.559 & 0.404 & 0.877 & 0.603 & 0.486 \\
\hline RISK_2 & 0.500 & 0.539 & 0.371 & 0.812 & 0.435 & 0.521 \\
\hline RISK_3 & 0.515 & 0.453 & 0.390 & 0.809 & 0.400 & 0.519 \\
\hline RISK_4 & 0.460 & 0.370 & 0.367 & 0.796 & 0.404 & 0.546 \\
\hline SEC_PRIV_1 & 0.428 & 0.581 & 0.278 & 0.498 & 0.784 & 0.432 \\
\hline SEC_PRIV_2 & 0.293 & 0.479 & 0.241 & 0.439 & 0.772 & 0.347 \\
\hline SEC_PRIV_3 & 0.413 & 0.537 & 0.294 & 0.511 & 0.848 & 0.434 \\
\hline SEC_PRIV_4 & 0.380 & 0.459 & 0.391 & 0.386 & 0.778 & 0.410 \\
\hline TRUST_1 & 0.464 & 0.424 & 0.398 & 0.530 & 0.444 & 0.787 \\
\hline TRUST_2 & 0.525 & 0.413 & 0.430 & 0.548 & 0.375 & 0.825 \\
\hline TRUST_3 & 0.475 & 0.407 & 0.501 & 0.527 & 0.413 & 0.797 \\
\hline TRUST_4 & 0.528 & 0.425 & 0.514 & 0.535 & 0.446 & 0.796 \\
\hline
\end{tabular}


Table 6. Heterotrait-Monotrait Ratio (HTMT)

\begin{tabular}{|l|c|c|c|c|c|c|}
\hline & $\begin{array}{c}\text { Intention to } \\
\text { adopt E-Payment } \\
\text { System }\end{array}$ & $\begin{array}{c}\text { Perceived } \\
\text { benefit }\end{array}$ & $\begin{array}{c}\text { Performance } \\
\text { expectancy }\end{array}$ & Risk & $\begin{array}{c}\text { Securi- } \\
\text { ty/privacy }\end{array}$ & Trust \\
\hline $\begin{array}{l}\text { Intention to adopt } \\
\text { E-Payment System }\end{array}$ & & & & & & \\
\hline Perceived benefit & 0.688 & & & & & \\
\hline $\begin{array}{l}\text { Performance } \\
\text { expectancy }\end{array}$ & 0.647 & 0.524 & & & & \\
\hline Risk & 0.750 & 0.753 & 0.615 & & & \\
\hline Security/privacy & 0.581 & 0.791 & 0.461 & 0.754 & & \\
\hline Trust & 0.740 & 0.618 & 0.685 & 0.841 & 0.645 & \\
\hline
\end{tabular}

\subsection{Structural model assessment}

In order to assess the structural model, the path analysis and coefficient of determination $\left(\mathrm{R}^{2}\right)$ were measured [50]. The predictive accuracy of the model is determined through the $\mathrm{R}^{2}$ value. As exhibited in Figure 2, the developed model explains $63.6 \%$ of the variance in the intention to adopt e-payment system. As demonstrated in Table 7, all the formulated hypotheses were accepted with an exception to hypothesis 4 . Hypothesis 1 suggested that perceived benefit has a positive impact on students' intention to adopt e-payment system. According to the results in Table 7 and Figure 2, it can be seen that there is a significant positive relationship between perceived benefit and the intention to adopt e-payment system $(\beta=0.265, \mathrm{p}<0.01)$. Hence, hypothesis 1 is accepted.

Hypothesis 2 suggested that perceived security/privacy has a negative impact on students' intention to adopt e-payment system. As per the results in Table 7 and Figure 2 , it can be noticed that there is a significant negative relationship between perceived security/privacy and the intention to adopt e-payment system $(\beta=0.210, p<$ 0.01). Therefore, hypothesis 2 is supported. Hypothesis 3 assumed that perceived risk has a negative impact on students' intention to adopt e-payment system. With respect to the results in Table 7 and Figure 2, it can be observed that there is a significant negative relationship between perceived risk and the intention to adopt e-payment system $(\beta=0.196, \mathrm{p}<0.05)$. Thus, hypothesis 3 is accepted.

Hypothesis 4 suggested that trust has a positive impact on students' intention to adopt e-payment system. As per the results in Table 7 and Figure 2, it is found that there is an insignificant relationship between trust and the intention to adopt epayment system $(\beta=-0.003, p>0.05)$. Hence, hypothesis 4 is rejected. Hypothesis 5 suggested that performance expectancy has a positive impact on students' intention to adopt e-payment system. According to the results in Table 7 and Figure 2, it can be seen that there is a significant positive relationship between performance expectancy and the intention to adopt e-payment system $(\beta=0.235, \mathrm{p}<0.01)$. Hence, hypothesis 5 is accepted. 
Table 7. Structural model results (significant at $\mathrm{p}^{* *}<=0.01, \mathrm{p}^{*}<0.05$ )

\begin{tabular}{|l|l|c|c|l|}
\hline $\mathbf{H}$ & \multicolumn{1}{|c|}{ Relationship } & Path Coefficient & $\boldsymbol{t}$-value & \multicolumn{1}{|c|}{ Decision } \\
\hline $\mathrm{H} 1$ & $\begin{array}{l}\text { Perceived benefit } \rightarrow \text { Intention to adopt E- } \\
\text { payment System }\end{array}$ & 0.265 & 2.966 & Supported** \\
\hline $\mathrm{H} 2$ & $\begin{array}{l}\text { Security/privacy } \rightarrow \text { Intention to adopt E- } \\
\text { payment System }\end{array}$ & 0.210 & 3.128 & Supported** \\
\hline $\mathrm{H} 3$ & $\begin{array}{l}\text { Risk } \rightarrow \text { Intention to adopt E-payment } \\
\text { System }\end{array}$ & 0.196 & 2.482 & Supported* \\
\hline $\mathrm{H} 4$ & $\begin{array}{l}\text { Trust } \rightarrow \text { Intention to adopt E-payment } \\
\text { System }\end{array}$ & -0.003 & 0.048 & Not supported \\
\hline $\mathrm{H} 5$ & $\begin{array}{l}\text { Performance expectancy } \rightarrow \text { Intention to } \\
\text { adopt E-payment System }\end{array}$ & 0.235 & 2.781 & Supported** \\
\hline
\end{tabular}

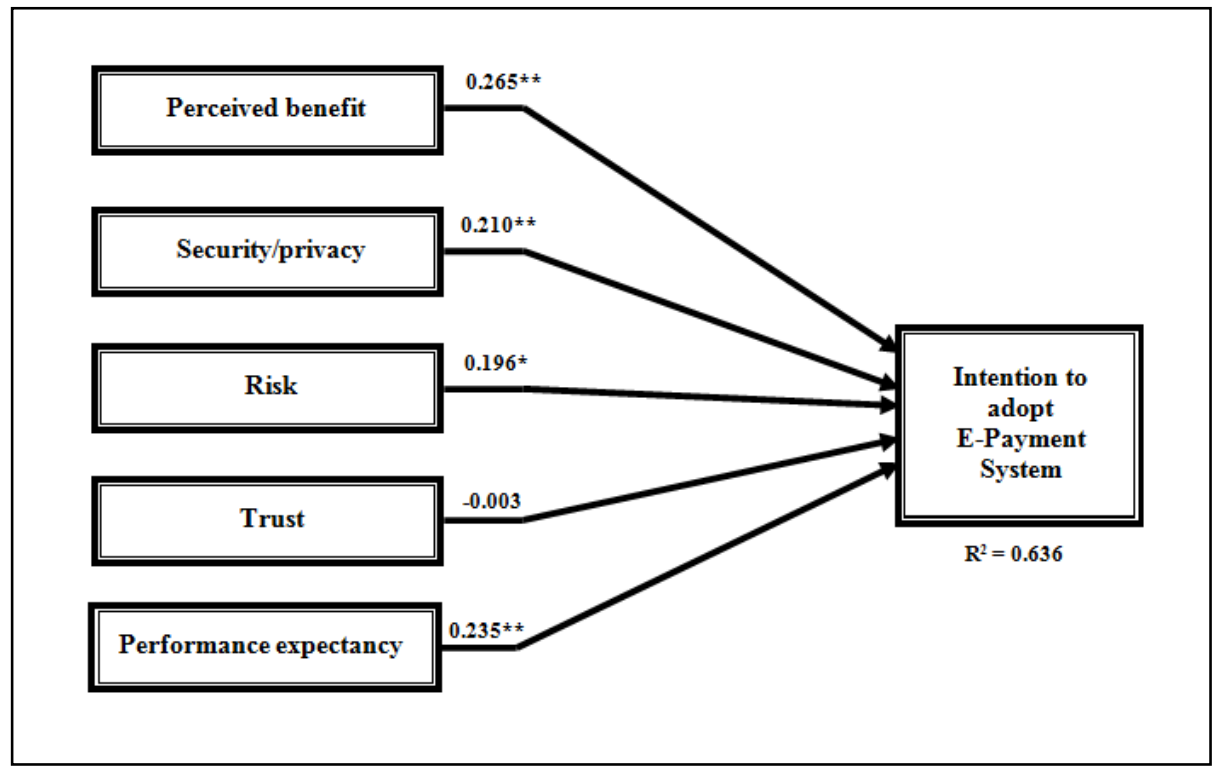

Fig. 2. Path analysis results (significant at $\mathrm{p}^{* *}<=0.01, \mathrm{p}^{*}<0.05$ )

\section{Conclusion}

\subsection{Contributions and implications}

Technology adoption has become a key research field by many information systems scholars, and this refers to the fact that the determinants affecting these technologies are varied from one context to the other [53]-[56]. E-payment systems are one of such technologies that attracted the attention of many scholars. The main purpose of this study is to gain an insight into the factors affecting the university students' intention to use e-payment systems in the UAE. This study proposed a new research model in which the students' intention to use the e-payment systems are affected by five different factors including perceived benefit, performance expectancy, perceived 
risk, perceived security/privacy, and trust. The findings indicated that perceived benefit and performance expectancy have a significant positive relationship with the students' intention to use e-payment systems. It was also found that perceived security/privacy and perceived risk have a significant negative relationship with the students' intention to use e-payment systems. These results were in agreement with the recent studies in the domain [11]-[13], [32]-[34]. Conversely, the results point out that trust has an insignificant relationship with the students' intention to use epayment systems. Additionally, the model explains $63.6 \%$ of the variance in the intention to use the e-payment systems.

Although several studies were conducted to examine the e-payment adoption, it was argued that there were a few number of studies undertaken in the higher educational institutions in general, and the UAE context in particular [10]. Therefore, this study and its findings contributed to the e-payment adoption literature by developing a new model that could be able to predict the students' intention to use the e-payment systems in the higher educational institutions in general, and the UAE context in particular.

\subsection{Limitations and future research directions}

While this study adds a significant contribution to the e-payment literature, it also has some limitations that needs to be considered while conducting further research. First, the data collection was constrained to the higher educational institutions in the UAE. Hence, caution is warranted when generalizing the results to other educational institutions contexts. Second, the study employed the convenience sampling technique in terms of data collection, which may limit the generalization of the research findings. Thus, further research should take this point into consideration.

\section{References}

[1] T. Moodley and I. Govender, "Factors influencing academic use of internet banking services: An empirical study,” African J. Sci. Technol. Innov. Dev., vol. 8, no. 1, pp. 43-51, 2016.

[2] M. C. Lee, "Factors influencing the adoption of internet banking: An integration of TAM and TPB with perceived risk and perceived benefit,” Electron. Commer. Res. Appl., 2009. https://doi.org/10.1016/j.elerap.2008.11.006

[3] M. C. Lee, "Predicting behavioral intention to use online banking," in Proceedings of the 19th international conference on information management. Taiwan, 2008.

[4] J. Keshav, "South African banks and their online privacy policy statements: A content analysis," South African J. Inf. Manag., vol. 12, no. 1, pp. 1-7, 2010. https://doi.org/10.4102/sajim.v12i1.418

[5] K. Al-Saedi, M. Al-Emran, E. Abusham, and S. A. El_Rahman, "Mobile Payment Adoption: A Systematic Review of the UTAUT Model," in International Conference on Fourth Industrial Revolution, 2019.

[6] S. Özkan, G. Bindusara, and R. Hackney, "Facilitating the adoption of e-payment systems: theoretical constructs and empirical analysis," J. Enterp. Inf. Manag., vol. 23, no. 3, pp. 305-325, 2010. https://doi.org/10.1108/17410391011036085 
[7] D. Abrazhevich, Electronic payment systems: A user-centered perspective and interaction design. Dennis Abrazhevich, 2004.

[8] E. K. F. Leong, M. T. Ewing, and L. F. Pitt, "Australian marketing managers' perceptions of the internet: a quasi-longitudinal perspective," Eur. J. Mark., vol. 37, no. 3/4, pp. 554571, 2003. https://doi.org/10.1108/03090560310459087

[9] D. K. Muzividzi, R. Mbizi, and T. Mukwazhe, "An analysis of factors that influence Internet banking adoption among intellectuals: Case of Chinhoyi University of Technology," Interdiscip. J. Contemp. Res. Bus., vol. 4, no. 11, pp. 350-369, 2013.

[10] S. A. Salloum and M. Al-Emran, "Factors affecting the adoption of E-payment systems by university students: Extending the TAM with trust," Int. J. Electron. Bus., vol. 14, no. 4, pp. 371-390, 2018. https://doi.org/10.1504/ijeb.2018.10019536

[11] A. A. Alalwan, Y. K. Dwivedi, and N. P. Rana, "Factors influencing adoption of mobile banking by Jordanian bank customers: Extending UTAUT2 with trust," Int. J. Inf. Manage., vol. 37, no. 3, pp. 99-110, 2017. https://doi.org/10.1016/j.ijinfomgt.2017.01.002

[12] D. Mehrad and S. Mohammadi, "Word of Mouth impact on the adoption of mobile banking in Iran," Telemat. Informatics, vol. 34, no. 7, pp. 1351-1363, 2017. https://doi.org/10.1016/j.tele.2016.08.009

[13] I. Sinha and S. Mukherjee, "Acceptance of technology, related factors in use of off branch e-banking: an Indian case study,” J. High Technol. Manag. Res., vol. 27, no. 1, pp. 88-100, 2016. https://doi.org/10.1016/j.tele.2016.08.009

[14] L. P. Chin and Z. A. Ahmad, "Perceived Enjoyment and Malaysian Consumers' Intention to Use a Single Platform E-Payment," in SHS Web of Conferences, 2015, vol. 18. https://doi.org/10.1051/shsconf/20151801009

[15] I. Ramos-de-Luna, F. Montoro-Ríos, and F. Liébana-Cabanillas, "Determinants of the intention to use NFC technology as a payment system: an acceptance model approach," Inf. Syst. E-bus. Manag., vol. 14, no. 2, pp. 293-314, 2016. https://doi.org/10.1007/s10257015-0284-5

[16] P. Upadhyay and S. Jahanyan, "Analyzing user perspective on the factors affecting use intention of mobile based transfer payment," Internet Res., vol. 26, no. 1, pp. 38-56, 2016. https://doi.org/10.1108/intr-05-2014-0143

[17] S. Abrol, "Role of Trust and Service Quality in E-Banking," Int. J. Banking, Risk Insur., vol. 4, no. 1, p. 1, 2016.

[18] S. I. Malik and M. Al-Emran, "Social Factors Influence on Career Choices for Female Computer Science Students," Int. J. Emerg. Technol. Learn., vol. 13, no. 5, pp. 56-70, 2018. https://doi.org/10.3991/ijet.v13i05.8231

[19] S. A. Salloum, C. Mhamdi, B. Al Kurdi, and K. Shaalan, "Factors affecting the Adoption and Meaningful Use of Social Media: A Structural Equation Modeling Approach,” Int. J. Inf. Technol. Lang. Stud., vol. 2, no. 3, 2018.

[20] S. A. Salloum, W. Maqableh, C. Mhamdi, B. Al Kurdi, and K. Shaalan, "Studying the Social Media Adoption by university students in the United Arab Emirates," Int. J. Inf. Technol. Lang. Stud., vol. 2, no. 3, 2018.

[21] Y. Leung, "Perceived Benefits," in Gellman M.D., Turner J.R. (eds) Encyclopedia of Behavioral Medicine, 2013.

[22] Y. Pei, S. Wang, J. Fan, and M. Zhang, "An empirical study on the impact of perceived benefit, risk and trust on e-payment adoption: comparing quick pay and union pay in China," in Intelligent Human-Machine Systems and Cybernetics (IHMSC), 2015 7th International Conference on, 2015, vol. 2, pp. 198-202. https://doi.org/10.1109/ihmsc.2015.148 
[23] W. Ming-Yen Teoh, S. Choy Chong, B. Lin, and J. Wei Chua, "Factors affecting consumers' perception of electronic payment: an empirical analysis," Internet Res., vol. 23, no. 4, pp. 465-485, 2013. https://doi.org/10.1108/intr-09-2012-0199

[24] D. J. Kim, D. L. Ferrin, and H. R. Rao, "A trust-based consumer decision-making model in electronic commerce: The role of trust, perceived risk, and their antecedents," Decis. Support Syst., 2008. https://doi.org/10.1016/j.dss.2007.07.001

[25] M. A. Nasir, J. Wu, M. Yago, and H. Li, "Influence of psychographics and risk perception on internet banking adoption: Current state of affairs in Britain," Int. J. Econ. Financ. Issues, vol. 5, no. 2, 2015.

[26] S. A. Olaleye, S. S. Oyelere, I. T. Sanusi, and J. F. Agbo, "Experience of Ubiquitous Computing Technology Driven Mobile Commerce in Africa: Impact of Usability, Privacy, Trust, and Reputation Concern,” Int. J. Interact. Mob. Technol., 2018. https://doi.org/10.3991/ijim.v12i3.7905

[27] M. Sathye, "Adoption of Internet banking by Australian consumers: an empirical investigation,” Int. J. bank Mark., vol. 17, no. 7, pp. 324-334, 1999. https://doi.org/10.1108/02652329910305689

[28] P. Pavlou, "Consumer acceptance of electronic commerce: integrating trust and risk with the technology acceptance model," Int. J. Electron. Commer., vol. 7, no. 3, pp. 69-103, 2003.

[29] T.-T. T. Pham and J. C. Ho, "The effects of product-related, personal-related factors and attractiveness of alternatives on consumer adoption of NFC-based mobile payments," Technol. Soc., vol. 43, pp. 159-172, 2015. https://doi.org/10.1016/j.techsoc.2015.05.004

[30] N. H. Al-Fahim, W. Jamaliah, and A. Abideen, "Altitudinal Factors Affecting the Adoption of Internet Banking Services among Small and Medium Enterprises in Yemen," in eLearning (econf), 2015 Fifth International Conference on, 2015, pp. 174-187. https://doi.org/10.1109/econf.2015.94

[31] C. Lin and C. Nguyen, "Exploring e-payment adoption in Vietnam and Taiwan," J. Comput. Inf. Syst., vol. 51, no. 4, pp. 41-52, 2011.

[32] Q. Yang, C. Pang, L. Liu, D. C. Yen, and J. M. Tarn, "Exploring consumer perceived risk and trust for online payments: An empirical study in China's younger generation," Comput. Human Behav., vol. 50, pp. 9-24, 2015. https://doi.org/10.1016/i.chb.2015.03.058

[33] W. Chaouali, I. Ben Yahia, and N. Souiden, "The interplay of counter-conformity motivation, social influence, and trust in customers' intention to adopt Internet banking services: The case of an emerging country," J. Retail. Consum. Serv., vol. 28, pp. 209-218, 2016. https://doi.org/10.1016/i.jretconser.2015.10.007

[34] K. Rouibah, P. B. Lowry, and Y. Hwang, "The effects of perceived enjoyment and perceived risks on trust formation and intentions to use online payment systems: New perspectives from an Arab country,” Electron. Commer. Res. Appl., vol. 19, pp. 33-43, 2016. https://doi.org/10.2139/ssrn.2810637

[35] M. Barkhordari, Z. Nourollah, H. Mashayekhi, Y. Mashayekhi, and M. S. Ahangar, "Factors influencing adoption of e-payment systems: an empirical study on Iranian customers," Inf. Syst. E-bus. Manag., vol. 15, no. 1, pp. 89-116, 2017. https://doi.org/10.1007/s10257016-0311-1

[36] V. Venkatesh, M. Morris, G. Davis, and F. Davis, "User acceptance of information technology: Toward a unified view,” MIS Q., vol. 27, no. 3, pp. 425-478, 2003. $\underline{\text { https://doi.org/10.2307/30036540 }}$

[37] H. Qasim and E. Abu-Shanab, "Drivers of mobile payment acceptance: The impact of network externalities," Inf. Syst. Front., vol. 18, no. 5, pp. 1021-1034, 2016. https://doi.org/10.1007/s10796-015-9598-6 
[38] M. Riffai, K. Grant, and D. Edgar, "Big TAM in Oman: Exploring the promise of on-line banking, its adoption by customers and the challenges of banking in Oman,” Int. J. Inf. Manage., vol. 32, no. 3, pp. 239-250, 2012. https://doi.org/10.1016/j.ijinfomgt. 2011.11.007

[39] C. Martins, T. Oliveira, and A. Popovič, "Understanding the internet banking adoption: A unified theory of acceptance and use of technology and perceived risk application," Int. J. Inf. Manage., vol. 34, no. 1, pp. 1-13, 2014. https://doi.org/10.1016/j.ijinfomgt. 2013.06.002

[40] M. Al-Emran and S. A. Salloum, "Students' Attitudes Towards the Use of Mobile Technologies in e-Evaluation," Int. J. Interact. Mob. Technol., vol. 11, no. 5, pp. 195-202, 2017. https://doi.org/10.3991/ijim.v11i5.6879

[41] R. A. S. Al-Maroof and M. Al-Emran, "Students acceptance of Google classroom: An exploratory study using PLS-SEM approach,” Int. J. Emerg. Technol. Learn., vol. 13, no. 6, pp. 112-123, 2018. https://doi.org/10.3991/ijet.v13i06.8275

[42] N. Al-Qaysi and M. Al-Emran, "Code-switching Usage in Social Media: A Case Study from Oman,” Int. J. Inf. Technol. Lang. Stud., vol. 1, no. 1, pp. 25-38, 2017.

[43] E. Erdfelder, F. FAul, A. Buchner, and A. G. Lang, "Statistical power analyses using G*Power 3.1: Tests for correlation and regression analyses," Behav. Res. Methods, 2009. https://doi.org/10.3758/brm.41.4.1149

[44] E. Ramirez, M. E. David, and M. J. Brusco, "Marketing's SEM based nomological network: Constructs and research streams in 1987-1997 and in 1998-2008," J. Bus. Res., 2013. https://doi.org/10.1016/j.jbusres.2012.02.022

[45] M. Al-Emran, V. Mezhuyev, and A. Kamaludin, "PLS-SEM in Information Systems Research: A Comprehensive Methodological Reference," in 4th International Conference on Advanced Intelligent Systems and Informatics (AISI 2018), 2018, pp. 644-653. https://doi.org/10.1007/978-3-319-99010-1 59

[46] R. Safeena, A. Kammani, and H. Date, "Assessment of internet banking adoption: An empirical analysis,” Arab. J. Sci. Eng., vol. 39, no. 2, pp. 837-849, 2014. https://doi.org/10.1007/s13369-013-0707-x

[47] S. Junadia, "A model of factors influencing consumer's intention to use e-payment system in Indonesia," 2015.

[48] P. Meharia, "ASSURANCE ON THE RELIABILITY OF MOBILE PAYMENT SYSTEM AND ITS EFFECTS ON ITS'USE: AN EMPIRICAL EXAMINATION," Account. Manag. Inf. Syst., vol. 11, no. 1, p. 97, 2012.

[49] C. M. Ringle, S. Wende, and A. Will, "SmartPLS 2.0 (Beta). Hamburg," Available in http://www. smartpls. de, 2005.

[50] J. F. Hair Jr, G. T. M. Hult, C. Ringle, and M. Sarstedt, A primer on partial least squares structural equation modeling (PLS-SEM). Sage Publications, 2016. https://doi.org/10.1108/ebr-10-2013-0128

[51] C. Fornell and D. F. Larcker, "Evaluating Structural Equation Models With Unobservable Variables and Measurement Error,” J. Mark. Res., vol. 18, no. 1, pp. 39-50, 1981. https://doi.org/10.1177/002224378101800104

[52] J. Henseler, C. M. Ringle, and M. Sarstedt, "A new criterion for assessing discriminant validity in variance-based structural equation modeling," J. Acad. Mark. Sci., vol. 43, no. 1, pp. 115-135, 2015. https://doi.org/10.1007/s11747-014-0403-8

[53] M. Al-Emran, Y. A. Alkhoudary, V. Mezhuyev, and M. Al-Emran, "Students and Educators Attitudes towards the use of M-Learning: Gender and Smartphone ownership Differences," Int. J. Interact. Mob. Technol., vol. 13, no. 1, pp. 127-135, 2019. https://doi.org/10.3991/ijim.v13i01.9374 
[54] V. Mezhuyev, M. Al-Emran, M. Fatehah, and N. C. Hong, "Factors affecting the Metamodelling Acceptance: A Case Study from Software Development Companies in Malaysia,” IEEE Access, vol. 6, pp. 49476-49485, 2018. https://doi.org/10.1109/access. $\underline{2018.2867559}$

[55] N. Al-Qaysi, N. Mohamad-Nordin, and M. Al-Emran, "A Systematic Review of Social Media Acceptance from the Perspective of Educational and Information Systems Theories and Models," J. Educ. Comput. Res., 2018. https://doi.org/10.1177/0735633118817879

[56] S. A. Salloum, M. Al-Emran, K. Shaalan, and A. Tarhini, "Factors affecting the E-learning acceptance: A case study from UAE," Educ. Inf. Technol., vol. 24, no. 1, pp. 509-530, 2019. https://doi.org/10.1007/s10639-018-9786-3

\section{Authors}

Said A. Salloum is the manager of computer center at University of Fujairah, Al Fujairah, UAE.

Mostafa Al-Emran is a researcher at Applied Computational Civil and Structural Engineering Research Group, Faculty of Civil Engineering, Ton Duc Thang University, Ho Chi Minh City, Vietnam.

Rifat Khalaf is an assistant professor in Accounting at University of Fujairah, Al Fujairah, UAE.

Mohammed Habes is a researcher at University of Fujairah, Al Fujairah, UAE.

Khaled Shaalan is a professor of Computer Science at Faculty of Engineering \& IT, The British University in Dubai, Dubai, UAE.

Article submitted 2018-11-18. Resubmitted 2019-04-02. Final acceptance 2019-04-21. Final version published as submitted by the authors. 